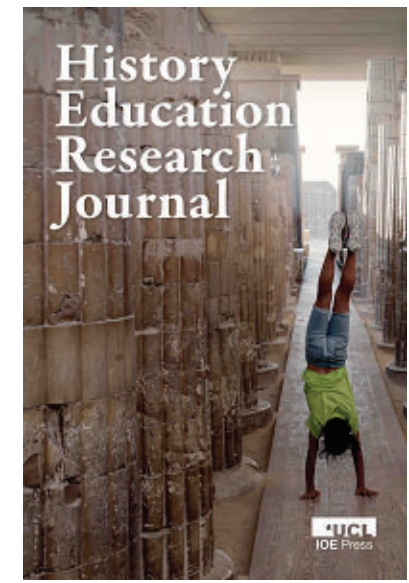

HISTORY EDUCATION RESEARCH JOURNAL

ISSN: 2631-9713 (Online)

Journal homepage:

https://www.ingentaconnect.com/content/ioep/herj

\title{
History teaching as a designed meaning-making process: Teacher facilitation of student-subject relationships
}

Heidi Eskelund Knudsen (D)

\section{How to cite this article}

Knudsen, H.E. (2020) 'History teaching as a designed meaning-making process: Teacher facilitation of student-subject relationships'. History Education Research Journal, 17 (1), 36-49. DOI https://doi.org/10.18546/HERJ.17.1.04

Submission date: 21 August 2019

Acceptance date: 6 November 2019

Publication date: 1 April 2020

\section{Peer review}

This article has been peer reviewed through the journal's standard double-blind peer review, where both the reviewers and authors are anonymized during review.

\section{Copyright}

(C) Copyright 2020 Knudsen. This is an Open Access article distributed under the terms of the Creative Commons Attribution Licence (CC BY) 4.0 https://creativecommons.org/licenses/by/4.0/, which permits unrestricted use, distribution and reproduction in any medium, provided the original author and source are credited.

\section{Open access}

The History Education Research Journal is a peer-reviewed open-access journal. 


\section{History \\ Education \\ Research \\ Journal}

\title{
History teaching as a designed meaning-making process: Teacher facilitation of student-subject relationships
}

\author{
Heidi Eskelund Knudsen* - University College Lillebaelt, Denmark
}

\begin{abstract}
This article is an empirical analysis of history teaching as a communicative process. Dialogic history teaching develops as a designed meaning-making process that depends on thorough pedagogical strategies and decisions, and requires cohesion in teacher expectations, introductions and interventions. A micro-dialogic study is presented in this article to document a paradoxical teaching situation where history as subject-related content all but disappeared from a group of students' meaning-making processes because they were preoccupied with figuring out their teacher's intentions. History teaching thus turned into 'just teaching' without the teacher or the students being aware of it. A strong emphasis on history teaching as a communicative process and dialogue as a key pedagogical tool have potential with regard to pedagogical decision-making and strategies on the one hand, and for relationships between students and history as subject-related content on the other. The analysis presented in this article contributes to a growing field of studies on dialogic history teaching, of which the focus on students as an important part of classroom dialogues is central.
\end{abstract}

Keywords: designed meaning-making; dialogic history teaching; student-subject relationship; history as communication; history didactics

\section{Introduction}

A fundamental aim of history teaching is the development of students' meaningmaking processes related to aspects of history. Opening up this relationship between students and history subject concerns explicit and well-communicated pedagogical strategies and decisions made by the history teacher. However, teachers often struggle to get a handle on which pedagogical strategies are required for what kind of student meaning-making process. Danish history teachers often describe a sense of a lack of coherence between students' meaning-making processes and history as subject content (Knudsen and Ebbensgaard, 2017; Poulsen and Knudsen, 2016). In general, they see history taught as a school subject as a bildung-oriented matter in a contemporary educational discourse of competence, skills and knowledge. It is challenging to link these different elements using pedagogical strategies and decisions while at the same time connecting students to history content (Knudsen and Ebbensgaard, 2017; Poulsen and Knudsen, 2016). However, the reasons for this have yet to be fully explicated.

History classes in Danish upper secondary schools are based on state curriculum content, which is interpreted and given life by history teachers according to their 
educational background. The state curriculum does not lay out prescribed content for teaching; instead, the formulations become educative as they are interpreted and transformed into teaching practice by teachers (Westbury, 2010). As part of this transformation, history teachers draw on a wide range of pedagogical practices and tools. Typically, history teaching comprises a variety of activities, such as whole-class dialogues, lecturing, small-group projects, student group work, oral presentations, documentary work, excursions, scenario-based role playing and games. Based on didaktik theory, the present article stresses that making such teaching work requires holistic reflections on several didactic elements (categories), for example, aim, content, media, methods, students' backgrounds and organizational context (Heimann, 1976, cited in Qvortrup and Bering Keiding, 2016: 164). A common premise in didaktik theory is that decisions related to one of the categories influence potential decisions in the others, and didactic practice must avoid contradictions between categories. Clarity and transparency are fundamental to quality in teaching (Meyer, 2004; Qvortrup and Bering Keiding, 2016: 164). From the didaktik perspective, history teaching (and the role of the teacher) concerns a complex matter of interrelated pedagogical issues, so communication - particularly dialogic teaching - is central to coherence and didactic clarity. Students' meaning-making processes and relationships with history as a subject depend on history teachers' didactical approaches to teaching as communication (Knudsen, 2018).

A lack of coherence and clarity regarding pedagogical strategies and decisions risks transforming history teaching into teaching without a lot of history. This can easily happen without the teacher (or the students) being aware of it. History as subjectrelated aspects risks becoming vague in students' meaning-making processes when or if they are preoccupied with discovering their teacher's intentions and understanding pedagogical information and interventions, which takes away their focus from subjectrelated aspects. In such cases, subject-related meaning-making is mainly expressed by the history teacher rather than the students.

In this article, empirical material from a study of Danish upper secondary history teaching is analysed using a specific case study, with the aim of demonstrating history teaching as a communicative process led and guided by the teacher - a process that affects students' meaning-making processes and relationships with history as subject content. The conceptual framework for analysing teaching as designed meaningmaking stems from designs for learning theory (Selander, 2008; Selander and Kress, 2012; Selander and Röstvall, 2010). The article consists of four sections. First, the relevant history education research focusing on dialogic history teaching will be examined. Second, the concept of designed meaning-making is described and defined in relation to the empirical analysis, which leads to the third section, a methodological section presenting the ethnographic background for the empirical material. Finally, the specific case being assessed is analysed and discussed, and the article is completed with conclusions.

\section{Dialogue in history classrooms}

A substantial body of Nordic and English-language research links classroom dialogue and discussion to general student learning processes (for example, Alexander, 2008, 2018; Cazden, 2001; Dysthe, 1997; Høegh, 2018, 2017; Haugsted, 1999; Nystrand et al., 1997). Studies on science and L1-language subjects in particular reveal a strong tradition of discussing aspects of classroom communication among qualified 
and trainee teachers (Høegh, 2018); among history teachers, however, similar discussions are rare. This absence may reflect the fact that classroom communication is pedagogically complex. In order to support and direct discussions about aspects of history as a subject matter, teachers must 'craft questions that open the content to investigation, and employ pedagogical moves that initiate students into sophisticated epistemological work' (Reisman et al., 2019: 146). How history teaching practices reflect this has not yet been fully explored by researchers. Furthermore, there is a lack of knowledge of how students' meaning-making processes develop and reflect how history teachers facilitate dialogic teaching.

To generate knowledge and contribute to history education and didactic research, this article refers to existing research on history teaching as communication. Although scholars use different concepts, such as whole-class discussion (Reisman, 2015; Reisman et al., 2018; Reisman et al., 2019), whole-class discourse (Van Drie and Van de Ven, 2017), dialogic teaching (Van Boxtel and Van Drie, 2013, 2017; Van Drie and Van Boxtel, 2011) and communication (Knudsen, 2018), these are all aspects of the same trend, namely using dialogue and communication as pedagogical tools to foster students' history knowledge and skills. Dialogic teaching refers to the fact that classroom dialogues (in contrast to everyday conversations) are often pedagogically planned (by a teacher) with the aim of engaging students in specific ways and to interconnect meaningful sequences during the process (Alexander, 2008, 2018; Høegh, 2018). Classroom dialogues may thus comprise shifting levels of student activity (Grant, 2018).

Interventional and design-based studies characterize much of the research on history teaching mentioned above. Using predesigned materials and teacherpreparation courses to promote document-based disciplinary whole-class discussions, Reisman and colleagues coded and analysed videotaped history lessons (Reisman, 2015; Reisman et al., 2018; Reisman et al., 2019). They found that disciplinary discussions are rare in US history classrooms, and that discussions that promote historical understanding are even rarer (Reisman, 2015). When disciplinary discussions do occur, teachers struggle to engage students in interpretative discussions (Reisman et al., 2019); they themselves also wrestle to formulate central historical questions capable of lifting discussions beyond a basic level (Reisman et al., 2018). In reflecting on two specific cases, Reisman argued that teacher facilitation and intervention are essential for meaningful student participation and discussion. In particular, teachers' use of textual press and uptake to push students to support claims with textual evidence and engage them in one another's ideas is vital (Reisman, 2015: 37). The statement reflects an implicit description and critique of US history teaching as being too focused on lecturing and recitation (as articulated in, for example, Bain, 2005; Reisman, 2015; Wineburg, 2001). Whole-class discussions therefore represent an argument in a general US teaching discussion about history as a school subject. Compared to this, Danish/Nordic classrooms are often rife with whole-class discussions, student talk and student-engaging activities (Høegh, 2018), but this has not proven to automatically develop student knowledge and skills in history. How talks in the classroom are used by both teachers and students to promote and facilitate what kind of activities and meaning-making are accomplished is also important (Haugsted, 1999).

From a different angle, Van Boxtel and Van Drie (2017) argued that well-prepared and formulated questions and student tasks matter. Students need to be 'triggered', so to speak, and questions that open up, deepen and widen students' train of thought 
are important to accomplishing this (ibid.). A key aspect of Van Boxtel and Van Drie's work concerned language and the learning of a subject language in order to take part in subject-related discussions (Van Boxtel and Van Drie, 2013, 2017; Van Drie and Van Boxtel, 2008, 2011). Like Reisman and colleagues, they examined how history teachers, as facilitators of dialogic teaching, act and use strategies to promote dialogic teaching with active student participation in discussions (Van Drie and Van Boxtel, 2011). Focusing on 'the history teacher' is indeed important as a way to gain insight into what goes on in teaching situations; however, because students' learning processes are at the heart of any teaching situation, it seems problematic not to include their responses to, or interpretations of, teacher information in research on dialogic teaching. Previous research has not adequately discussed how dialogic teaching as meaning-making interactions between teachers and students develops and causes different teaching effects for the students.

In this article, an ethnographic and explorative approach is used to investigate micro-studies of what history teaching as a communicative process looks like and becomes when teachers and students arrange and engage in talks about history content. In that sense, and compared to the research mentioned above, this article represents a non-interventional research approach. History teaching understood as a designed meaning-making process constitutes an alternative angle to investigate and reflect on assumptions about what goes on in history teaching situations.

This article is a contribution to the small field of studies on dialogic history teaching, particularly the focus on students as an important part of classroom dialogues, which is central. Dialogic teaching that develops as designed meaningmaking processes, which in turn depend on thorough pedagogical preparations regarding cohesion in teacher introductions and interventions, is examined. The analysis presented below illustrates how what might at first seem to be teaching about history as a subject easily risks devolving into 'just teaching' in the absence of pedagogical coherence and clarity.

\section{Theory: Designed meaning-making processes}

History teaching studied as a communicative and meaning-making process refers to the designs for learning theory, which relies on social semiotic and sociocultural theories (Selander, 2008; Selander and Kress, 2012; Selander and Röstvall, 2010). In particular, the social semiotic part of the designs for learning theory emphasizes communicative processes and the roles of sign-making and sign-interpretation practices in dialogic micro-situations as a means of access to study meaning-making and learning processes in teaching situations (Kress, 2010; Selander, 2008). According to the theory, learning can be seen as a social activity where signs in different media (information) are elaborated and where new signs in new media are formed (reconfiguration and recontextualization) (Selander, 2008: 12). Consequently, learning refers to the capacity to form and use signs and engage meaningfully in different situations through interpretative processes (Selander, 2010).

Meaning-making in schools is clearly framed by many different internal and external school factors (Selander, 2008: 16; Selander and Kress, 2012). The use of signs and interpretations in the design process is embedded in formalized expectations, outcomes and assessment procedures with the clear goal of producing new representations (Selander, 2008: 16). All of this is marked in transformation units of the meaning-making process (see the model presented in Figure 1). 


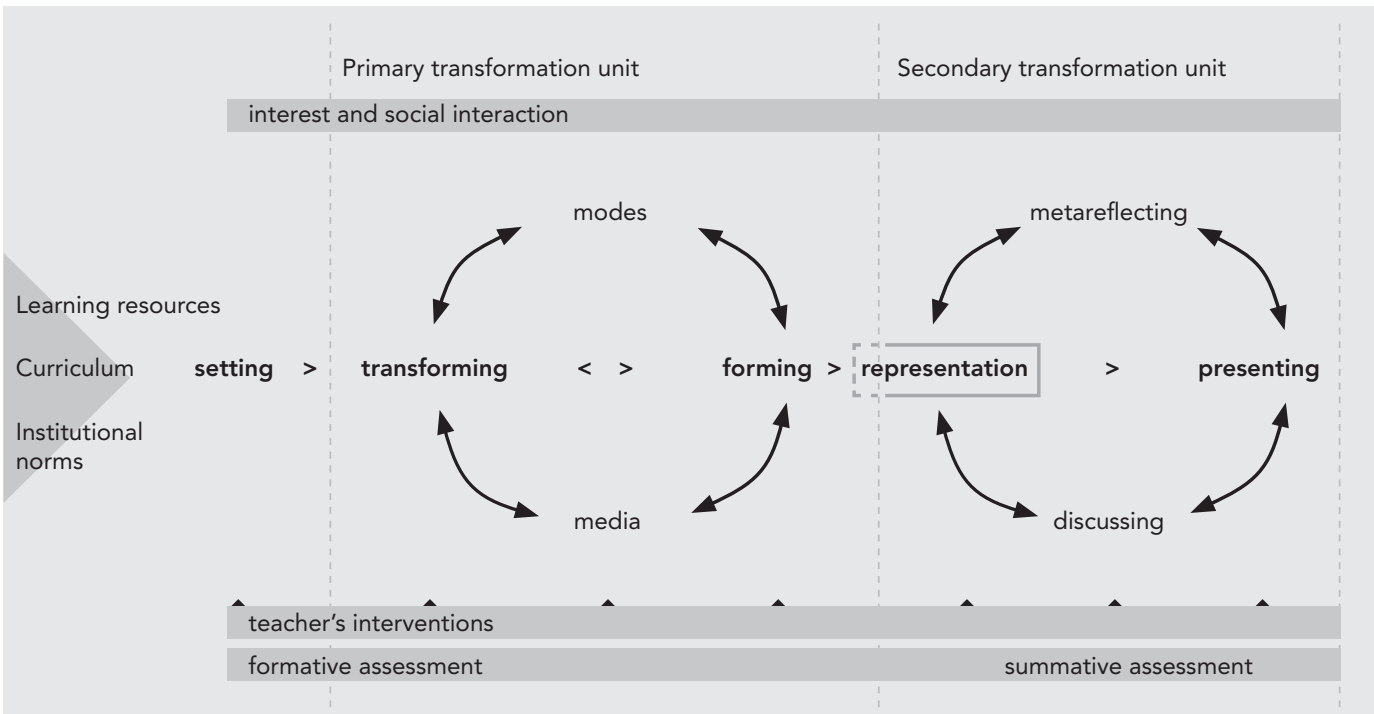

Figure 1: The formal learning design sequence

Source: Adapted from Selander (2008: 17)

The formal learning design sequence model (LDS) illustrates the communicative meaning-making process. A sequence begins when a teacher introduces a task, topic, question or the like, and sets the scene and conditions for the work. As mentioned above, the setting of the process is highly influenced by various factors, including curricula, learning resources, the teacher's background, institutional norms, values and the students' conceptions of a subject. Although these factors are important for understanding the designed meaning-making process at a macro level, this discussion is strongly focused on the dialogic micro-situations in order to explicate how history teaching develops as a specific meaning-making process caused by interactions between history teachers and students regarding aspects of history.

Regarding dialogic micro-situations, students' interpretations and transformation of a task and its setting take place in a primary transformation unit (see Figure 1). Using different modes and media, they form and express signs of meaning as they try to handle the information provided by the teacher. The transformation unit reflects how students engaged in a dialogue seek and adapt to information, as well as arrange and collaborate on establishing meaning-making. Furthermore, interactions between both teachers and students and students and learning materials can be observed and analysed as part of the unit. As portrayed in the LDS model, boundaries between the primary and secondary transformation units are not entirely evident, and the process does not progress linearly. However, according to the theory, in the secondary transformation unit, students present their work and explain how they have understood and designed their meaning-making. Throughout the process, from setting to primary and secondary transformation units, the teacher intervenes and responds to the students' signs of meaning-making in order to support, encourage, correct, direct (and so on) how the students approach given information (Selander, 2008; Selander and Kress, 2012: 99; Selander and Röstvall, 2010). Because the teacher is as much a factor in the meaning-making process as the students, the impact of teacher interventions is an important part of the analytical approach to dialogic micro-situations. Questions such as how the teacher intervenes, at what level and in relation to which pedagogical aspects are crucial to the discussion on history teaching as a communicative process. In 
the present article, these specific elements and the LDS model in particular are referred to when analysing and discussing matters of setting, interpretation, transformation and interventions in dialogic micro-situations between history teachers and students.

\section{Method: The background of empirical material and a case study}

As mentioned, this article relies on empirical material. During the 2015/16 school year, together with a colleague, I conducted ethnographic field studies at nine Danish primary and upper secondary schools (Knudsen and Ebbensgaard, 2017). The aim of the study was initially to investigate the aspects of coherence and transition in students' moving from history as a school subject at the ninth-grade (final year) primary school level into upper secondary history teaching (a different school context). Due to the different educational backgrounds of the teachers in the two school forms, the transition from one school context to another in subjects such as Danish, maths and English proves to be challenging for many students (Ebbensgaard et al., 2014). We were therefore curious to study experiences regarding history as a school subject.

The ethnographic field strategy was based on participant observations with simultaneous combinations of document analysis (state curriculum content, learning materials, teaching plans and student notes), interviews with teachers and students as respondents and informants, direct participation, observations and introspections (Adler and Adler, 1998; Angrosino and Mays de Pérez, 2000; Atkinson and Hammersley, 1998; Denzin, 2009; Flick, 2009; Hammersley and Atkinson, 1995, 1996). The particular aim of the participatory approach was to gain access to meaning-making and interactions as viewed from the perspectives of the history teachers and students involved. During the in-depth observational study, a great amount of empirical material was gathered and produced, including transcribed field notes and sound recordings from dialogic teaching situations. In the present article, a specific case study of one history lesson in a first-year class at a provincial Danish upper secondary school of approximately one thousand students is examined.

The specific case regards a history lesson where the teacher, Helle, and her 24 students were covering the Constitutional Act of Denmark (1849) as part of a sixweek course on different forms of governance in Danish political history. Helle has been teaching for seven years. She is well-liked by her students and her teaching encompasses a variety of activities, ranging from strong teacher control to encouraging active and independent engagement between the students. Regarding the topic in question, the Danish Constitutional Act of June 1849 marked a change in Danish national history from absolute to constitutional monarchy and democracy. In line with the didactic categories mentioned earlier, the pedagogical aim of the lesson was, according to Helle, to make the students aware of and reflect on the historical changes and consequences from both a historical and a modern contemporary societal perspective. She introduced her students to content consisting of historical sourcebased group work on text extracts from the 1849 Constitution. The students worked in groups of four, arranged by Helle according to their backgrounds and qualifications. One group of four students was followed for this analysis. The task for the students consisted of two parts. First, the students were asked to understand the text. Second, they had to answer two questions: 'To whom did political power belong after the Constitution of 1849?' and 'What are the rights of the individual?' The specific lesson took place on 26 January 2016, from 9.55 to 11.25 a.m. 
As an empirical foundation for this article, the case study of Helle and her students illustrates a paradigmatic example or pattern (Flyvbjerg, 2010: 476) in a Danish upper secondary history class, and demonstrates how a teaching situation was organized and performed by the participants. Apart from the teacher's introduction, the lesson consisted of student group work, which is often used by Danish history teachers as a pedagogical tool to encourage student engagement and variations in teaching activities. History lessons usually end in common classroom-based discussions and evaluations of the task and student products. History teaching often develops within an instructional frame of these three separate, albeit connected, sequences. The particular focus of the present article is the first two sequences. For the purpose of this article, all quotations have been translated and presented in English, and to maintain the confidentiality of the participants, they have been given pseudonyms.

\section{Analysis, results and discussion}

A continuous and descriptive analysis of the case is presented below. With reference to the LDS model, the teacher introduction and setting-up of the process went as follows:

Helle: First of all, you need to understand this text, this historical source, and then ... our problem formulation regarding the investigation of the text will be ... [writes on blackboard] 'To whom did political power belong after the Constitution of 1849, and what are the rights of the individual?' In other words, the Constitution is our topic for today, and we have to draw out knowledge from pieces of this constitutional text, a law text. In addition, the method we will be using is source criticism. You will join your groups and we will meet up again in here at around 11.00.

This instruction was part of a longer introduction where Helle referred to both former lesson content and student homework in order to facilitate the present task and group work situation. As illustrated, her introduction was loaded with information and student demands. The students were asked to 'understand the text' in order to further answer two specific questions with the purpose of 'drawing out knowledge'. They were introduced to the text as a 'historical source' and 'a law text', the topic was 'the Constitution of 1849' and 'source criticism' was mentioned as the specific method. The introduction framed the students' working process from the beginning to the end of the lesson, and required the students to be able to grasp information that reflected both history-subject-oriented and general pedagogical aspects.

How the four students handled and interpreted the information was immediately revealed by observing the primary transformation unit. Characteristically, their interpretation of the information first revolved around how to understand the given task and the wealth of information involved. The students spent a significant amount of time discussing how to understand the teacher's expectations, how to deal with language issues, how to organize group roles and different responsibilities and so on. Second, and after having started concrete text readings, their meaning-making process consisted of reading passages aloud, discussing and negotiating extensively regarding their comprehension and understanding of the content. Listening to them read aloud, it became clear that accurately understanding the text of a law written in the Danish of 1849 was challenging for them. They often stumbled over words and sentences, were uncertain of the correct pronunciation of some words and were uneasy about the process. However, they seemed determined to achieve meaning-making, as they continuously presented their understandings to each other, negotiating 
and establishing syntheses of common meaning-making. Only rarely did they look up words. The following conversation illustrates a part of this working process. One student, Liv, read a paragraph aloud while the others listened. Another student, Camilla, was primarily engaged in translating and interpreting the text:

Liv: All right. [Reads aloud] 'All limitations regarding a free and equal access to occupation which is not justified in common interests are to be abolished through legislation ...' [mumbles, lowers her voice].

Dennis: Hmn ...?

[Silence as they read the passage.]

Liv: I'm gonna be the worst lawyer ever.

Dennis: This doesn't make any sense.

Camilla: [In the middle of writing notes] We can always look up words if we need to. Try and read it again, I wasn't paying attention.

Liv: 'All limitations regarding a free and equal access to occupation which is not justified in common interests ...' [interrupts herself] So you are not allowed to conduct 'black work' [undeclared work] or ...? [laughs a bit].

[Silence]

Camilla: It's kind of fun to be reading these old law texts ... I don't know, I think maybe you are right.

Liv: Yes, isn't it? ... You're not allowed to conduct 'black work' [Camilla laughs].

Camilla: No black work [she writes].

Liv: No, I'm not sure about this.

Camilla: OK, so mark the sentence. We can always return to this.

This exchange reveals the students' meaning-making of a paragraph in the Constitution regarding the right to work as a tradesman. (The original passage reads: 'Alle Indskrænkninger i den frie og lige Adgang til Erhverv, som ikke ere berundede i det almene Vel, skulle hæves ved Lov' (Danmarkshistorien.dk, n.d.: §88).) They were clearly designing and establishing didactical direction on their own, although the teacher's introduction and pedagogical order to 'understand the text' was evident as the actual frame and direction of the process. As part of the process, and in order to complete the task, they referred to everyday knowledge, which consequently turned 'the right to work as a tradesman' into a 'prohibition on undeclared work'. One might speak of this as a specific sign of students' represented meaning-making, although incorrect meaning-making happens to be the case here. Clearly, the students' working process, as well as how they have been prepared for the task, did not match the requirements necessary to arrive at the proper answer, mainly due to the fact that the language of the law text was difficult for them. According to the LDS model, teacher interventions appear to be part of the designed learning process as pedagogical tools. Shortly after the conversation quoted above, Helle approached the group to ask them about their process:

Helle: What are you guys working on?

Dennis: Paragraph 88

[Camilla explains that they have been writing down keywords for all the paragraphs of the text.]

Helle: Oh no, not for each and every one, I hope?

Camilla: [quickly] No, of course not [this is in fact what they had been doing]. 
Helle: You don't have to do it one by one. Surely, if you find it necessary in order to ... you know ... get a bit of an umbrella view on things, then it's all right. But what I want you to do is to write down - at a general level - the kind of rights which the Danish citizens gained here.

The teacher intervention obviously responded to the students' signs of meaningmaking and the designed learning process, and consequently corrected the outcome and added to the task. One of the first things Helle did was to ask the students to take a more 'general' perspective on the text. In that sense, and to the students, the original task and information regarding 'understanding the text' changed at that point. However, one could see Helle's reaction as a sign of how she thought, and how she understood the coherence between the pedagogical orders to 'understand the text' and 'write at a general level'. The coherence between how the student task introduced was formulated and how the teacher's intentions are signalled to the students on the one hand, and, on the other hand, what the teacher actually intends to make the students learn, is crucial. Helle commented a moment after she read and responded to the students' notes:

Helle: No, this has nothing to do with undeclared work [laughs]. This is about some of the things you've been reading about in your homework for today. Number 88 is about the right to settle down as a tradesman. You're now allowed to open a carpentry business in town if you want to before the 1849 Constitution, people had to apply for permission and the permission was only provided by the local guild. So, this has nothing to do with black working or avoiding paying tax.

As this comment illustrates, Helle interrupted the students not only to refute their misconceptions, but also to explain and contextualize the historical facts in order to help and support their meaning-making in the 'right' direction. Clearly, she revealed to her students how their meaning-making process was not about any kind of meaningmaking but about her specific intentions and understanding as a teacher, although the signs of this intention seemed to change during the process. As illustrated below, the students clearly became confused. Moreover, the process was further muddled by the fact that Helle also signalled that the students' role was to figure out her intentions on their own. The specific teaching situation therefore seemed to end paradoxically. As illustrated below, the students' meaning-making process changed, returning to a primary transformation situation in response to the new information they received. Their attention and meaning-making process was transformed and redesigned from the original task ('understanding the text') into what one might define as 'figuring out the teacher's intentions'. As seen below, the students signalled doubts about Helle's expectations of their meaning-making process, and the dialogue then shifted from an explicit focus on the law text as a history-related issue to a teaching moment that brought the students' confusion and questions into focus. The students seemed eager to 'guess' where the teacher wanted them to ' $g o$ ':

Liv: All right ... so it's a bit the same as gaining the right to form associations and to access teaching and ...

Helle: Yes, exactly ... and if you were to put this in more general terms, then what would you say? ... You are about to get to the issue.

Liv: [hesitates] ... that we ... got the right to ... a lot of things? [laughs a bit]

[Camilla repeats some of notes they have been writing.]

Camilla: or what do you mean? 
From an analytical point of view, it is interesting to see how the teacher intervention caused the students to shift immediately away from history-related aspects. The meaning-making process turned to and focused on the students' attempts to decipher the teacher's intentions, rather than history as subject matter. The exchange highlights the difficulty of the process for the students, and because throughout the dialogue the students continued to struggle to understand the teacher's apparently paradoxical information and pedagogical guidelines, a moment later Helle ended up providing the students with the concrete point about her intentions and the answer to the task:

Helle: Well, we are speaking of a change here, a change from the former system of government, from absolute monarchy where there was no freedom of speech, no rights to unite and join associations or to be brought before a judge. Before 1849, people were not allowed to arrange public meetings and discussions about things they were dissatisfied with. The king and his government officials were regulating and restricting the society at all levels. But in June 1849, suddenly people were allowed to express themselves ... and that is exactly the important part here.

Liv: So ... civil rights are about gaining the freedom to speak?

Helle: Yes, and freedom of assembly and ... is that an odd word for you?

Liv: Yes, we don't really use that kind of word.

Helle: All right, then, I want you to write notes in your own words because now you know what the text means.

The quoted dialogue documents meaning-making as a designed and developing process where the setting and original task demanded of the students changed during the process. The teacher set the task and the students interpreted, transformed and (re)presented meaning-making. The teacher interpreted this meaning-making, intervened, corrected the task and informed the students anew - according to her intentions and the set conditions of the teaching - but also in line with the meaningmaking process, which the students themselves designed and began (by taking notes, for example). Clearly, specific and consistent teacher intentions guided the dialogic content and process, but a lack of clarity and transparency regarding coherence between aim, content, methods and so on, also confused the students. The quoted dialogue revealed little about the relationship between the students and history as subject matter; the primary focus was Helle's designed meaning-making and her understanding of history as discipline and subject matter. The students' understanding of the same was somewhat less apparent. Instead, their meaning-making process reflected doubts about what was expected of them. This confusion and doubt seemed to prevent the student-subject relationship from ever developing.

Studies of classroom interactions and dialogues in history teaching point to the fact that history teachers often struggle to engage students in subject-related aspects and discussions (Reisman et al., 2019), and that they find it difficult to raise and conduct discussions beyond low-level questions (Reisman et al., 2018). It is possible that history didactic and educational considerations focus more on how the pedagogical strategies and teacher selections underpinning history teaching influence students' opportunities to engage with aspects of history as a subject. How the questions asked signal teacher intentions and expectations of students - and therefore represent (history subject) information to be transformed and interpreted in students' meaningmaking processes - is crucial. In this case, Helle seemed to be hindering the process and her own intentions by introducing and formulating the task in the way that she did. Furthermore, she made it difficult for the students to reach a point where their 
meaning-making process focused more on history as subject-related content than figuring out teacher intentions.

In looking at where and how history subject-related aspects actually do appear during dialogic micro-situations, teacher utterances stand out distinctly. During her introduction, Helle referred to subject-related aspects when she talked about the Danish Constitutional Act as a historical object and event. She mentioned source criticism as the method and asked the students to answer subject-related questions. In addition to and during the process, she pointed to history subject concepts such as change versus continuity, and she contextualized the historical event in order to support the students' meaning-making process. In other words, she expressed many signs of disciplinary thinking. The students, on the other hand, were interacting with an aspect of history as a subject (the law text), but their meaning-making process seemed primarily concerned with the pedagogical order (the demanded task) and the information Helle provided. They focused on the intention and expectations of their teacher. The role of the teacher is therefore an important part of the student-subject relationship.

One might add that the students' work on the 1849 law text represented an indirect 'encounter with the past' and was therefore related to history as a subject, which entered and played a role in the students' meaning-making process. However, because Helle did not explicitly address this fact as part of her introduction, neither did it become a conscious part of the students' meaning-making process. The students simply worked with a specific disciplinary aspect, a representation of the past, without knowing that they were doing so or reflecting on it, probably because they were not explicitly asked to do so as part of the task. Moreover, Helle only responded moderately to the fact that the students obviously found it challenging to read a document written in 1849. As illustrated in the introduction to the task, Helle did not give attention to a close reading of the text or textual analysis as part of the process. According to the designs for learning theory, students often approach subject-related written texts without thinking carefully or critically about the source (Selander, 2010: 43); they usually do not understand that meta-perspective angles on textual analysis represent an important part of a meaning-making process. Teachers must therefore address this explicitly when introducing a task. Furthermore, Helle could have addressed the role of the text and language of the law as part of the meaning-making process, thereby supporting the students' work on, and experience with, history as subject matter. The presented case seems to illustrate the point that teaching cases often lack clear, welldefined teaching goals and pedagogical strategies designed to enable teachers to notice signs of meaning-making and learning during the process (Selander, 2008: 17). This could be either because students' learning processes are taken for granted to some extent or because the teacher's important role as a facilitator of students' meaningmaking processes is ignored. As mentioned above, Helle could have introduced the students to the historical text and been more explicit about it as a subject-related matter, but she made other pedagogical decisions.

Both the present analysis and the research literature highlight the challenging task of ensuring that students are exposed to aspects of history as a subject in ways that are significant to their meaning-making processes. The present article suggests a further focus on teaching as a communicative and meaning-making process where coherence between introductions and the teacher's interventions and intentions are important. In the presented case, the vagueness of history as a subject is a consequence of the lack of attention paid to the role of the history teacher as a pedagogical facilitator of meaningmaking processes. As seen in the students' exchanges, signs of meaning-making that 
concern history as a subject matter are rare or weak. If one takes a critical view of this case, the students either struggled to understand the task and/or the complicated language used in the Constitution, or they tried to fit shifting information about teacher intentions into their meaning-making process. Overall, the students were left with few opportunities to actually relate to history as a subject matter, even though that was Helle's aim. It is worth noticing that, based on impressions from the ethnographic field studies in 2016, neither the researchers, as participant observers, nor the teacher or students disagreed with being engaged in a history teaching situation; it was only afterwards, during the close micro-studies of specific dialogues and signs of meaningmaking, that the findings were made. From a student perspective, history teaching can therefore take place without incorporating a lot of history subject content, and thus it is important to focus on clearly explained tasks and expectations at the beginning of a designed meaning-making process.

\section{Conclusion}

Through an empirical analysis of history teaching as a communicative process, this article has documented how meaning-making is constantly designed and redesigned as a result of interactions between teachers and students. History teaching - as well as teaching in general - is a complex matter. However, despite the fact that all teaching strategies have advantages and constraints, it is important to clearly explain teacher expectations regarding the process and goal to students at the beginning of a meaning-making process. Furthermore, signs of introduced teacher expectations must be aligned with teacher interventions later on. History teaching as a communicative process is thus strongly emphasized and dialogue is highlighted as a key pedagogical tool for creating coherence and relationships between students and history as a school subject.

\section{Notes on the contributor}

Heidi Eskelund Knudsen is Associate Professor at HistoryLab, a research centre at the Department for Applied Research in Pedagogy and Society at University College Lillebaelt, Denmark. Her research focuses on history subject-oriented didactics, teacher competencies and developments, and students' meaning-making processes in history teaching.

\section{References}

Adler, P.A. and Adler, P. (1998) 'Observational techniques'. In Denzin, N.K. and Lincoln, Y.S. (eds) Collecting and Interpreting Qualitative Materials. Thousand Oaks, CA: SAGE Publications, 79-109.

Alexander, R. (2008) Essays on Pedagogy. London: Routledge.

Alexander, R. (2018) 'Developing dialogic teaching: Genesis, process, trial'. Research Papers in Education, 33 (5), 561-98.

Angrosino, M.V. and Mays de Pérez, K.A. (2000) 'Rethinking observation: From method to context'. In Denzin, N.K. and Lincoln, Y.S. (eds) Handbook of Qualitative Research. 2nd ed. Thousand Oaks, CA: SAGE Publications, 673-702.

Atkinson, P. and Hammersley, M. (1998) 'Ethnography and participant observation'. In Denzin, N.K. and Lincoln, Y.S. (eds) Strategies of Qualitative Inquiry. Thousand Oaks, CA: SAGE Publications, 110-36.

Bain, R.B. (2005) " "They thought the world was flat?": Applying the principles of How People Learn in teaching high school history'. In Donovan, M.S. and Bransford, J.D. (eds) How Students Learn. Washington, DC: National Academies Press, 179-214. 
Cazden, C.B. (2001) Classroom Discourse: The language of teaching and learning. 2nd ed. Portsmouth, NH: Heinemann.

Danmarkshistorien.dk (n.d.) 'Danmarks Riges Grundlov, 5. juni 1849 (Junigrundloven)'. Online. https://tinyurl.com/cgbv3z6 (accessed 7 January 2020).

Denzin, N.K. (2009) The Research Act: A theoretical introduction to sociological methods. Somerset, NJ: Aldine Transaction.

Dysthe, O. (1997) Det flerstemmige klasserum: Skrivning og samtale for at lære. Aarhus: Klim.

Ebbensgaard, A.H.B., Jacobsen, J.C. and Ulriksen, L. (2014) Overgangsproblemer mellem grundskole og gymnasium i fagene dansk, matematik og engelsk. Copenhagen: Institut for Naturfagenes Didaktik.

Flick, U. (2009) An Introduction to Qualitative Research. 4th ed. London: SAGE Publications.

Flyvbjerg, B. (2010) 'Fem misforståelser om casestudiet'. In Brinkmann, S. and Tanggaard, L. (eds) Kvalitative metoder. Copenhagen: Hans Reitzel, 463-87.

Grant, S.G. (2018) 'Teaching practices in history education'. In Metzger, S.A. and McArthur Harris, L. (eds) The Wiley International Handbook of History Teaching and Learning. Hoboken, NJ: WileyBlackwell, 419-48.

Hammersley, M. and Atkinson, P. (1995) Ethnography: Principles in practice. 2nd ed. London: Routledge.

Hammersley, M. and Atkinson, P. (1996) Feltmetodikk. Oslo: Ad Notam Gyldendal.

Haugsted, M.T. (1999) Handlende mundtlighed: Mundtlig metode og æstetiske læreprocesser. Copenhagen: Danmarks Lærerhøjskole.

Heimann, P. (1976) Didaktik als Unterrichtswissenschaft. Stuttgart: Klett.

Høegh, T. (2017) 'Methodological issues in analysing human communication: The complexities of multimodality'. In Duncker, D. and Perregaard, B. (eds) Creativity and Continuity: Perspectives on the dynamics of language conventionalisation. Copenhagen: U Press, 83-127.

Høegh, T. (2018) 'Faglig mundtlighed og den mundtlige undervisnings former'. In Christensen, T.S., Elf, N., Hobel, P., Qvortrup, A. and Troelsen, S. (eds) Didaktik i udvikling. Aarhus: Klim, 131-51.

Knudsen, H.E. (2018) 'Viden mellem elev og fag - historieundervisning som dynamisk kommunikation'. Nordidactica: Journal of Humanities and Social Science Education, 1, 45-64.

Knudsen, H.E. and Ebbensgaard, A.B. (2017) Historie på langs af skoleformer - sammenhænge og progression mellem grundskole og gymnasier. Jelling: HistorieLab.

Kress, G. (2010) Multimodality: A social semiotic approach to contemporary communication. London: Routledge.

Meyer, H. (2004) Was ist guter Unterricht? Berlin: Cornelsen Scriptor.

Nystrand, M., Gamoran, A., Kachur, R. and Prendergast, C. (1997) Opening Dialogue: Understanding the dynamics of language and learning in the English classroom. New York: Teachers College Press.

Poulsen, J.A. and Knudsen, H.E. (2016) Historiefaget i fokus - dokumentationsindsatsen. Jelling: HistorieLab.

Qvortrup, A. and Bering Keiding, T. (2016) 'The mistake to mistake learning theory for didactics'. In Qvortrup, A., Wiberg, M., Christensen, G. and Hansbøl, M. (eds) On the Definition of Learning. Odense: University Press of Southern Denmark, 163-88.

Reisman, A. (2015) 'Entering the historical problem space: Whole-class text-based discussion in history class'. Teachers College Record, 117 (2), 1-44.

Reisman, A., Cipparone, P., Jay, L., Monte-Sano, C., Schneider Kavanagh, S., McGrew, S. and Fogo, B. (2019) 'Evidence of emergent practice: Teacher candidates facilitating historical discussions in their field placements'. Teaching and Teacher Education, 80, 145-56.

Reisman, A., Schneider Kavanagh, S., Monte-Sano, C., Fogo, B., McGrew, S.C., Cipparone, P. and Simmons, E. (2018) 'Facilitating whole-class discussions in history: A framework for preparing teacher candidates'. Journal of Teacher Education, 69 (3), 278-93.

Selander, S. (2008) 'Designs for learning: A theoretical perspective'. Designs for Learning, $1(1), 10-22$.

Selander, S. (2010) 'Tecken för lärande - tecken på lärande: Ett designteoretiskt perspektiv'. In Selander, S. and Röstvall, A.-L. (eds) Design för lärande. Stockholm: Norstedts, 28-44.

Selander, S. and Kress, G. (2012) Læringsdesign - i et multimodalt perspektiv. Copenhagen: Frydenlund.

Selander, S. and Röstvall, A.-L. (eds) (2010) Design för lärande. Stockholm: Norstedts.

Van Boxtel, C. and Van Drie, J. (2013) 'Historical reasoning in the classroom: What does it look like and how can we enhance it?'. Teaching History, 150, 44-52. 
Van Boxtel, C. and Van Drie, J. (2017) 'Engaging students in historical reasoning: The need for dialogic history education'. In Carretero, M., Berger, S. and Grever, M. (eds) Palgrave Handbook of Research in Historical Culture and Education. London: Palgrave Macmillan, 573-89.

Van Drie, J. and Van Boxtel, C. (2008) 'Historical reasoning: Towards a framework for analyzing students' reasoning about the past'. Educational Psychology Review, 20 (2), 87-110.

Van Drie, J. and Van Boxtel, C. (2011) '"In essence I'm only reflecting": Teacher strategies for fostering historical reasoning in whole-class discussions'. International Journal of Historical Learning, Teaching and Research, 10 (1), 55-66.

Van Drie, J. and Van de Ven, P.-H. (2017) 'Moving ideas: An exploration of students' use of dialogue for writing in history'. Language and Education, 31 (6), 526-42.

Westbury, I. (2010) 'Teaching as a reflective practice: What might didaktik teach curriculum?'. In Westbury, I., Hopmann, S. and Riquarts, K. (eds) Teaching as a Reflective Practice: The German didaktik tradition. New York: Routledge, 15-39.

Wineburg, S. (2001) Historical Thinking and Other Unnatural Acts: Charting the future of teaching the past. Philadelphia: Temple University Press. 